\title{
PENEGAKAN DIAGNOSIS PENYAKIT JANTUNG KORONER DENGAN PROSEDUR UJI LATIH JANTUNG
}

\author{
Oleh: Novita Intan Arovah \\ Dosen Jurusan Pendidikan Kesehatan dan Rekreasi \\ FIK Universitas Negeri Yogyakarta
}

\begin{abstract}
Abstrak
Penyakit jantung koroner merupakan penyakit degeneratif yang disebabkan oleh gangguan vaskularisasi pada arteria koronaria jantung. Gangguan vaskularisasi tersebut dapat menimbulkan kematian jaringan jantung yang dikenal sebagai infark miokardium. Pada gangguan dengan derajat berat, manifestasi klinis dapat timbul pada saat beraktivitas maupun pada saat beristirahat, sedangkan pada derajat gangguan yang ringan manifestasi klinis baru muncul pada saat penderita melakukan aktivitas berat.

Pada penderita dengan derajat yang ringan, kelainan ini sukar untuk didiagnosis karena biasanya, manifestasi klinis yang berupa nyeri dada, perubahan rekaman elektrokardiografi serta ekokardiografi tidak muncul pada saat dilakukan pemeriksaan. Oleh karenanya pada penderita dengan riwayat nyeri dada berulang dengan kecurigaan gangguan jantung perlu dilakukan suatu aktivitas yang dirancang untuk meningkatkan kerja jantung agar dapat memunculkan manifestasi klinis yang ada sehingga diagnosis penyakit jantung koroner dapat ditegakkan dengan mantap. Aktivitas ini dikenal sebagai uji latih jantung.
\end{abstract}

Kata kunci: penyakit jantung koroner- uji latih jantung

Penyakit jantung koroner merupakan keadaan yang ditimbulkan oleh gangguan vaskularisasi arteri koronaria. Gangguan tersebut dapat berupa kekakuan dinding pembuluh darah atau proses arteriosklerosid maupun yang timbul akibat terbentuknya plak ateroma yang menyumbat pembuluh darah jantung atau 
dikenal sebagai proses aterosklerosis. Proses pembentukan ateroma erat kaitannya dengan keseimbangan metabolisme lemak serta kerja radikal bebas, sedangkan proses arteriosklerosis merupakan suatu proses degeneratif yang dipengaruhi oleh banyak faktor terutama faktor usia (Rahman, 1996). Penyakit ini sering timbul pada usia di atas 40 tahun yang merupakan usia produktif serta dapat menimbulkan kematian mendadak. Penyakit jantung koroner tercatat sebagai penyebab dari $35 \%$ kematian pada pria berumur 50-60 tahun di Amerika Serikat. Pada keadaan lanjut seperti infark miokardium, angka kematian dalam 1 tahun adalah sebesar $10 \%$, dalam 3 tahun $15-25 \%$, sedangkan dalam 10 tahun sebesar $50 \%$ (Kusmana, 1996). Mengingat besarnya insidens penyakit ini serta dampak yang ditimbulkannya, penyakit jantung koroner ini penting untuk dikaji lebih lanjut.

Gejala awal yang timbul pada proses gangguan vaskularisasi arteria koronaria adalah serangan rasa nyeri pada dada sebelah kiri yang dapat dilokalisasi oleh penderita (Guyton, 1997). Rasa nyeri tersebuit pada keadaan lanjut dapat terjadi sec?ra spontan tanpa harus didahului dengan aktivitas fisik yang berat. Pada keadaan lanjut seperti ini pemeriksaan jantung seperti rekam jantung dapat dilakukan sewaktu-waktu dan dapat memperoleh hasil yang akurat sedangkan pada tahap awal, rekaman jantung yang didapatkan dari penderita yang cukup beristirahat cenderung memperlihatkan hasil yang normal. Oleh karenanya untuk melakukan penegakan diagnosis kelainan kardiovaskuler yang tidak dapat ditemukan pada saat istirahat diperlukan suatu desain aktivitas yang mampu meningkatkan kerja jantung (Verani, Weiner dan Yanowitz, 2000).

\section{PENYAKIT JANTUNG KORONER}

Untuk menjamin optimalitas kerja jantung, harus terjadi keseimbangan antara suplai oksigen dan kebutuhan oksigen miokardium. Pengurangan suplai oksigen atau peningkatan kebutuhan oksigen akan mengganggu keseimbangan tersebut, sehingga membahayakan fungsi miokardium (Guyton, 1997).

Pada saat beristirahat maupun beraktivitas, otot jantung hampir selalu memerlukan oksigen. Agar kebutuhan oksigen pada saat beraktivitas dapat terpenuhi, aliran koroner harus ditingkatkan dengan jalan melebarkan arteri koronaria. Pada keadaan normal aliran darah koroner saat beraktivitas dapat ditingkatkan sampai lima kali lebih besar daripada pada saat istirahat. Peningkatan tersebut dilakukan dengan jalan meningkatkan frekuensi denyut jantung dan 
meningkatan isi sekuncup jantung (stroke volume) sehingga keluaran jantung (cardiac output) dapat meningkat. Peningkatan cardiac output tersebut yang pada akhirnya dapat meningkatkan aliran pada arteri koronaria sehingga, kebutuhan jaringan otot jantung terhadap oksigen dapat terpenuhi. Proses pelebaran pembuluh darah ini dapat terhambat apabila terjadi kekakuan pembuluh darah yang dapat disebabkan oleh proses penuaan maupun proses timbunan lemak. Pada keadaan tersebut arteria koronaria tidak dapat melebar sehingga terjadi kekurangan oksigen pada saat kebutuhan oksigen meningkat. Keadaan ini menimbulkan suatu gejala klinis yang dinamakan sindroma insufisiensi koroner (Guyton, 1997).

Manifestasi klinis penyakit jantung koroner sangat bervariasi dan bergantung pada tingkat aliran darah pada arteri koroner serta derajat peningkatan kebutuhan miokardium terhadap oksigen. Apabila aliran darah masih mencukupi kebutuhan jaringan miokardium, gejala klinis tidak akan terjadi sedangkan apabila aliran darah sudah tidak mampu mencukupi kebutuhan, gejala klinis akan timbul (Kusmana, 1996).

Faktor yang mempengaruhi aliran darah koroner meliputi dua hal yakni anatomi jantung serta sistem autoregulasi jantung (Guyton, 1997). Secara anatomis terlihat bahwa arteri koroner tidak seluruhnya berada pada permukaan jantung akan tetapi justru sebagian besar terdapat dalam miokardium. Pada saat sistole, jantung berkontraksi sehingga terjadi kompresi yang kuat pada otot ventrikel di sekeliling arteri koronaria. Hal ini akan menimbulkan hambatan aliran darah pada cabang koroner yang berada jauh dalam miokardium. Pada keadaan diastole otot jantung berelaksasi sehingga aliran darah koroner tidak terhambat dan darah dapat mengalir dengan cepat. Oleh karenanya dapat dipahami bahwa aliran darah koroner $80 \%$ terjadi pada saat diastole dan $20 \%$ terjadi pada saat sistole. Volume aliran darah koroner juga ditentukan oleh besarnya penampang arteri koronaria. makin kecil penampang arteri koronaria, makin kecil pula aliran darah yang dapat melewatinya (Rahman, 1996)

Sistem autoregulasi jantung didasari oleh kebutuhan oksigen jaringan serta keseimbangan saraf simpatis dan parasimpatis. Otot polos pada arteri koronaria mampu melakukan adaptasi dengan melakukan kontraksi maupun dilatasi sebagai respons terhadap kebutuhan otot jantung terhadap oksigen. Rangsangan simpatis dapat meningkatkan frekuensi dan kapasitas kontraksi jantung. Hal ini pada akhirnya akan meningkatkan derajat metabolisme jantung serta menimbulkan dilatasi arteri koroner. Sebaliknya respon parasimpatis akan memperlambat jantung dan menimbulkan konstriksi arteri koronaria (Kusmana, 1996). 
Ketidakseimbangan suplai dan kebutuhan yang berupa penurunan suplai darah pada keadaan kebutuhan normal ataupun kebutuhan oksigen yang meningkat pada suplai darah yang menetap merupakan mekanisme dasar terjadinya sindrom insufisiensi koroner. Pada keadaan stenosis atau spasme arteri koronaria, suplai darah oleh arteri koroner tidak bisa mencukupi kebutuhan otot jantung. Manifestasi klinik yang dapat terjadi bervariasi sesuai dengan berat ringannya stenosis atau spasme, peningkatan kebutuhan jaringan serta luas daerah yang terpengaruh.

Pada keadaan istirahat, stenosis lumen arteri koronaria sampai $60 \%$ belum menimbulkan gejala karena aliran koroner masih mampu mencukupi kebutuhan jaringan. Keadaan ini sering disebut sebagai penyakit jantung koroner laten. Pada keadaan ini apabila terjadi peningkatan kebutuhan jaringan, aliran yang semula mencukupi kebutuhan menjadi kurang. Keadaan ini menimbulkan hipoksia jaringan yang memaksa miokardium untuk mengubah metabolisme yang semula bersifat aerobik menjadi metabolisme anaerobik. Hasil akhir metabolisme anaerobik adalah berupa asam laktat yang akan menurunkan $\mathrm{pH}$ sel dengan manifestasi klinik berupa nyeri dada, rasa berat, rasa tertekan, rasa tercekik, perasaan tidak enak di dada ataupun rasa lelah. Manifestasi klinis yang timbul pada saat istirahat, menunjukkan bahwa stenosis sudah terjadi lebih dari $60 \%$. Bila hipoksia berlangsung lama, akan dapat terjadi kerusakan otot jantung berupa nekrosis atau yang dikenal dengan infark miokardium (Irawan, 1997)

Aterosklerosis koroner merupakan puriyebab penyakit arteri koronaria yang paling sering ditemukan. Proses tersebut terjadi secara kronis dengan mekanisme awal berupa penimbunan sejumlah besar kolesterol di bawah endotel yang kemudian diinvasi oleh jaringan fibrosa dan sering kali mengalami kalsifikasi. Hasil akhir proses tersebut adalah terbentuknya plak aterosklerosis yang menonjol ke dalam lumen dan secara progresif mempersempit lumen pembuluh. Gangguan aterosklerosis ini sering timbul pada bagian proksimal segmen epikardial arteri koronaria serta pada tempat-tempat yang melengkung secara tiba-tiba maupun tempat percabangan (Trisnohadi, 1996).

Selain penyempitan arteri koroner yang berlangsung progresif, terdapat faktor lain yang berperan pada terjadinya penyakit jantung koroner yakni disfungsi endotel, faktor inflamasi serta infeksi beberapa mikroorganisme seperti clamidia pneumonia dan sitomegalovirus. Pengaruh fungsional akibat menyempitnya pembuluh koroner selain meningkatkan tahanan di daerah tersebut juga menurunkan tekanan perfusi di bagian distal cabang koroner. Selama masih 
terdapat kemampuan untuk melakukan kompensasi melalui cabang kolateral yang belum mengalami sklerosis, otot jantung belum akan mengalami hipoksia. Iskemia miokardium baru terjadi jika cadangan koroner tidak lagi mampu mengkompensasi kebutuhan oksigen jaringan. Oleh karenanya pada tahap awal, nyeri dada baru muncui pada saat penderita sedang melakukan aktivitas fisik yang berat (Rahman, 1996).

Pada saat terjadi iskemia, manifestasi hemodinamik yang sering terjadi adalah peningkatan tekanan darah serta frekuensi denyut jantung sebelum timbul nyeri dada. Hal ini merupakan respons dari simpatis akibat fungsi miokardium yang berkurang. Penurunan tekanan darah timbul bila daerah yang terserang iskemia luas atau merupakan respons parasimpatis nervus vagus. Serangan iskemia biasanya mereda jika suplai dan kebutuhan oksigen sudah mencapai keseimbangan.

\section{UJI LATIH JANTUNG}

Uji latih jantung merupakan suatu uji latihan fisik yang dipergunakan untuk mengukur kondisi kardiovaskuler dengan mendeteksi perubahan hemodinamika, iskemia, dan gangguan irama jantung yang berhubungan dengan aktivitas fisik tersebut. Uji latih jantung merupakan suatu uji stres fisiologis yang bertujuan memunculkan ketidaknormalan kerja jantung yang bersifat laten atau yang tidak terjadi pada saat istirahat. (Heiger, 1996).

Pada saat aktivitas fisik terjadi beberapa pengaturan dalam sistem regulasi sirkulasi darah yakni pertama terjadi peningkatan respons saraf simpatis sehingga frekuensi denyut serta kerja pemompaan jantung menjadi meningkat, kedua terjadi kenaikan tekanan arteri karena sebagian besar arteriola pada sirkulasi perifer menjadi terkonstriksi kecuali sistem koroner dan serebral serta ketiga terjadi kontriksi vena sehingga terjadi peningkatan pengisian jantung (venous return) (Yanowitz, 2000)

Uji latih jantung harus dilaksanakan oleh tenaga yang terlatih serta mempunyai dasar pengetahuan fisiologi latihan. American Heart Association Exercise Standard menyatakan bahwa uji latih jantung harus dilaksanakan di bawah pengawasan dokter yang terlatih dalam melakukan uji latih jantung dan bertanggung jawab untuk memastikan bahwa laboratorium latihan dilengkapi dengan peralatan, obat-obatan, dan tenaga ahli untuk resusitasi jantung pulmonal (Verani, 2000). 
Walaupun prosedur uji latih jantung pada penderita secara umum dianggap aman, masih terdapat laporan terjadinya kematian yang diduga timbul karena infark miokardium akut pada saat dilakukan uji latih jantung. Risiko terbesar ini dapat terjadi pada penderita post infark miokard dan penderita aritmia ventrikel maligna. Dari berbagai macam protokol pelaksanaan uji latih jantung ini, tidak satu pun prosedur yang cocok untuk semua orang. Pada prinsipnya beban latihan dimulai dari tingkat yang biasa mampu ditoleransi oleh penderita dan dinaikkan secara bertahap baik intensitas maupun waktunya untuk mencapai steady state. Hal ini penting guna memonitor keluhan seperti nyeri dada, pusing, kelelahan, kenaikan tekanan darah, frekuensi jantung serta perubahan EKG atau tercapainya target frekuensi jantung (Weiner, 2000).

Pada saat uji latih jantung dimulai, pengambilan oksigen oleh paru dengan cepat meningkat akan tetapi setelah beberapa menit, pengambilan oksigen biasanya relatif stabil pada tiap tingkatan latihan. Selama masa steady state, frekuensi jantung, cardiui sintput, tekanan darah serta ventilasi paru dipertahankan pada level konstan. Jumlah oksigen yang paling besar yang dapat diambil selama uji latih jantung disebut komsumsi oksigen maksimum serta merupakan gambaran jumlah transpor oksigen serta penggunaannya pada metabolisme sel. Hal ini sangat berguna untuk mengekspresikan pengambilan oksigen pada keadaan istirahat. Satu unit pengambian oksigen pada saat istirahat disebut The Metabolic Equivalen (MEt) bernilai 3,5 $\mathrm{ml} \mathrm{O}_{2} / \mathrm{kgBB} /$ menit. The Metabolic Equivalen (MEt) tersebut dipakai untuk menunjukkan beban berbagai tingkatan dari protokol uji latih jantung (Heiger, 1997).

Tabel 1, Hubungan antara Kelas Fungsional dan METs

\begin{tabular}{|c|c|}
\hline Tipe individu & Kualitas latihan \\
\hline Kelas I & $6-10$ METs \\
\hline Kelas & 4-6 METs \\
\hline Kelas III & $2-3$ METs \\
\hline Kelas IV & 1 METs \\
\hline
\end{tabular}




\section{Indikasi Uji Latih Jantung}

Uji latih jantung diindikasikan terutama untuk (1) menegakkan atau menyingkirkan kemungkinan penyakit jantung koroner, (2) menentukan kapasitas fungsional jantung, serta untuk (3) mengevaluasi hasil pengobatan atau tindakan operasi untuk penyakit jantung koroner. Indikasi lain adalah untuk (4) menentukan lebih lanjut suatu aritmia, (5) tujuan skrining untuk maksud tertentu seperti asuransi jiwa, (6) rehabilitasi penderita penyakit jantung, serta untuk (7) tujuan penelitian (Yanowitz, 2000). ,

\section{Kontraindikasi Uji Latih Jantung}

Uji latih jantung tidak boleh dilakukan apabila terdapat kontraindikasi dari kardiovaskuler, seperti (1) angina tidak stabil, (2) aritmia yang serius, (3) stenosis aorta berat, (4) gagal jantung berat, (5) miokarditis, (6) perikarditis atau endokarditis aktif, (7) AV blok derajat II dan III, (8) hipertensi tidak terkontrol (sistole $>220 \mathrm{mmHg}$, diastole $>120 \mathrm{mmHg}$ ), (9) tromboflebitis akut serta (10)kardiomiopati. Kelainan nonkardiovaskuler yang dikontraindikasikan adalah (11) infeksi aktif, (12) gangguan emosi berat, (13) penyakit metabolik tidak terkontrol seperti tirotoksikosis, miksedema atau diabetes melitus, (14) gangguan neuromuskuler, (15) gangguan muskuloskletal atau gangguan sendi, serta (16) gangguan sistemik lain yang menyebabkan latihan tidak bisa dilakukan dengan baik (Yanowitz, 2000) .

\section{Efek Samping Uji Latih Jantung}

Efek samping yang dapat terjadi pada jantung dapat berupa: (1) bradikardi, (2) sudden death (ventricular tabycardia/fibrillation), (3) infark miokardium, (4) gagal jantung, (5) hipotensi serta (6) syok. Efek samping lain yang dapat terjadi dapat berupa: (7) letih, (8) pusing, (9) lemah, (10) pingsan, dan (11) nyeri otot yang dapat berlangsung selama beberapa hari (Verani, 2000). 


\section{Prosedur Uji Latih Jantung Persiapan}

Sebelum dilakukan uji latih jantung terhadap penderita, perlu dilakukan persiapan khusus antara lain penderita tidak diperbolehkan makan atau merokok paling sedikit 2 - 3 jam sebelum uji latih dilaksanakan serta tidak melakukan pekerjaan berat selama 12 jam sebelumnya. Pemakaian obat yang dapat mengganggu respons latihan serta menimbulkan keraguan interpretasi terhadap uji latih juga harus dihentikan dalam 24 jam sebelum dilakukan uji latih. Hal yang penting untuk dilakukan adalah anamnesis serta pemeriksaan fisik untuk menghindari kemungkinan adanya kontraindikasi, penjelasan mengenai prosedur latihan, risiko dan komplikasi yang mungkin terjadi serta dilakukannya EKG standar 12 sadapan (lead) ketika istirahat sebelum latihan dimulai (Verani, 2000).

\section{Peralatan dan protokol}

Peralatan yang paling sering digunakan adalah treadmill dan sepeda ergometer. Treadmill mempunyai kecepatan yang bervariasi serta kemampuan yang bertingkat. Untuk menjaga keseimbangan selama uji latih jantung penderita dapat memakai bantuan jalur tangan. Latihan dimulai dari tingkatan terendah yang mampu ditoleransi oleh penderita sampai kemudian diakhiri pada tingkat kesulitan maksimal yang mampu ditoleransi. Terdapat tiga protokol yang dipakai untuk treadmill yaitu protokol Bruce, Cornell, dan Naughton. Protokol yang paling populer untuk digunakan adalah protokol Bruce. Protokol ini sering dipakai karena memiliki validitas yang lebih cermat (Weiner, 2000).

Protokol Cornel dapat dipakai pada penderita dengan toleransi beban latihan terbatas karena peningkatan beban kerjanya yang lebih kecil, sedangkan protokol Naughton sering digunakan untuk penderita post infarct myocard untuk membedakan penderita yang masuk kategori risiko tinggi dan resiko rendah serta untuk membuat strategi pengobatan yang optimal (Verani, 2000).

Dengan mempergunakan sepeda ergometer, nilai tertinggi dari $\mathrm{VO}_{2}$ dan frekuensi jantung dapat dicapai dengan kecepatan pedal $60-80 \mathrm{rpm}$. Latihan dengan sepeda dimulai dengan tahanan minimal selama beberapa menit dan kemudian diberi beban yang dinaikkan secara bertingkat dengan penambahan 15 sampai 25 watt setiap 1 atau 2 menit dengan lama uji 8 sampai dengan 12 menit. Dengan memakai sepeda ergometer, gerak tubuh bagian atas minimal 
sehingga lebih mudah untuk mengukur tekanan darah serta membuat rekaman EKG (Verani, 2000).

\section{Indikasi penghentian latihan}

Selama latihan denyut jantung, tekanan darah dan frekuensi napas harus selalu dimonitor. Pada beberapa kasus, uji latih jantung diakhiri pada saat penderita mencapai denyut jantung $90 \%$ dari prediksi maksimum sesuai umur dan derajat latihan. Target denyut,jantung yang didesain berlainan pada setiap subjek. Target dapat maksimum, melampaui batas atas maksimum maupun submaksimum. Uji dikatakan maksimum apabila penderita melakukan usaha maksimum yang sebenarnya (mencapai titik kelelahan tubuh). Latihan dihentikan bila terdapat indikasi absolut berupa penurunan tekanan darah atau frekuensi denyut jantung dengan naiknya beban latihan, timbul keluhan nyeri dada, timbul gejal s cistem saraf pusat (pusing, sinkop, ataksia), gangguan perfusi perifer (sianosis, flushing), aritmia berat atau penderita minta untuk dihentikan. Indikasi relatif yang dapat dipertimbangkan untuk menghentikan latihan adalah depresi atau elevasi segmen ST yang nyata at $(\geq 2 \mathrm{~mm})$, rasa tidak enak di dada bertambah, sesak nafas, klaudikasio intermiten, takikardi,supraventrikuler ventrikel ekstrasistole frekuen, bundle branch block serta hipertensi nyata (sistole $>220 \mathrm{mmHg}$, diastole $>110 \mathrm{mmHg}$ ) (Yanowitz, 2000)

\section{Monitor jantung pada uji latih jantung}

Pemantauan keadaan jantung pada uji latih jantung dapat dilakukan dengan memakai elektrokardiografi, ekokardiografi, atau perfusion imaging. Pemantauan keadaan jantung pada saat uji latih jantung dilakukan untuk menentukan diagnosis bagi penderita. Informasi dasar yang diperlukan meliputi data sebelum, selama dan sesudah uji latih jantung dilakukan (Irawan, 1997)

\section{Elektrokardiografi}

Perubahan yang dievaluasi pada elektrokardiografi adalah perubahan segmen ST yang meliputi depresi segmen ST tipe iskemia, elevasi segmen ST, serta perubahan gelombang $\mathrm{T}$. 
Segmen ST merupakan segmen terpenting dalam perekaman elektrokardiografi. Adanya perubahan segmen ST berupa depresi maupun elevasi merupakan penanda terjadinya gangguan pada jantung. Tes dalam uji latih jantung dikatakan positif apabila didapatkan perubahan segmen ST (depresi atau elevasi sebesar $1 \mathrm{~mm}$ atau lebih) pada saat latihan atau sesudahnya. Segmen ST mengalami depresi dalam bentuk garis lurus yang harizontal atau garis yang agak cembung dan miring ke bawah dan kemudian membelok ke atas seperti bulan sabit. Pola tersebut merupakan kriteria diagnosis iskemia miokardium.

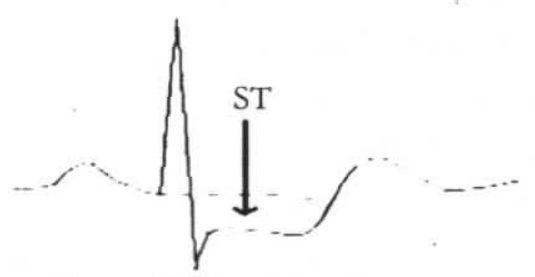

a. Depresi ST tipe iskemik

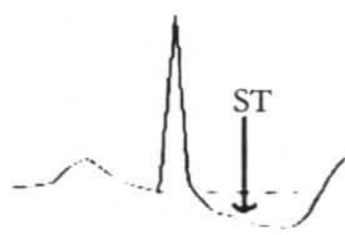

b. Depresi ST tipe ickle

Gambar 1. Depresi Segmen ST pada Uji Latih Jantung

Segmen ST dapat mengalami elevasi berbentuk pelana dengan konkavitas menghadap ke atas. Elevasi segmen ST yang diikuti oleh depresi segmen ST pada lead atau sadapan yang merupakan kebalikannya merupakan indikasi iskemia serius dengan risiko komplikasi akut pada miokardium bersangkutan.

Perubahan gelombang $\mathrm{T}$ dapat terjadi bersamaan dengan elevasi segmen ST, maupun berdiri sendiri. Beberapa penulis beranggapan bahwa penurunan gelombang $\mathrm{T}$ selama atau setelah uji latih jantung sebanyak $25 \%$ dari harga pada saat istirahat belum merupakan petunjuk yang definitif, sedangkan apabila penurunan $>50 \%$ kemungkinan merupakan petunjuk adanya insufisiensi koroner yang bermakna. Inversi gelombang $\mathrm{T}$ yang bersifat mendadak dianggap patologik apabila bersamaan dengan elevasi segmen ST. Keadaan ini merupakan salah satu petunjuk prognosis yang buruk (Sugiri, 1996).

\section{Ekokardiografi}

Ekokardiografi merupakan suatu prosedur pencitraan yang mempergunakan gelombang ultrasonik. Prosedur tersebut bersifat noninfasif serta tidak menggunakan ionisasi radiasi yang berbahaya. Ekokardiografi dipergunakan untuk menilai keadaan jantung pada uji latih jantung. Keuntungan penggunaannya 
antara lain adalah sensitivitas serta spesifitasnya sebanding dengan exercise nuclear imaging, dapat diperoleh informasi yang lebih luas tentang penyakit koroner, hasil segera tersedia, portabel, waktu terpakai sedikit serta biayanya lebih rendah dibandingkan dengan exercise nuclear imaging.

Berbagai parameter pada ekokardiografi dapat dipergunakan untuk menentukan fungsi ventrikel, ukuran ruangan, tebal dinding serta fungsi katup. Keuntungan yang lain adalah metode tersebut sangat teliti untuk mediagnosis penyakit arteri koroner pada keadaan LBBB. Kekurangan metode ini adalah interprestasi hasilnya sangat subjektif serta tidak terdapat standar baku dan sukar menginterprestasikan kelainan yang ada (Irawan, 1997).

Ekokardiografi pada uji latih jantung dipergunakan pada (1) penderita dengan elektrokardiografi istirahat yang abnormal ( $\mathrm{LVH}, \mathrm{LBBB}$, efek digitalis, depresi segmen ST), (2) penderita dengan kemungkinan hasil elektrokardiografi positif palsu serta (3) penderita yang menjalani prosedur terapeutik seperti angioplasty atau pembedahan pintas (Irawan,1997).

\section{Perfusion Imaging}

Perfusion imaging merupakan metode untuk menilai aliran darah miokardium dengan mempergunakan zat radiologis. Zat radiologis yang banyak dipergunakan adalah talium 201. Jaringan jantung menyerap talium 201 sebanding dengan aliran darah ke daerah tersebut. Makin besar perfusi darah ke daerah miokardium makin banyak ambilan talium 201 di daerah tersebut. Jika terjadi penurunan atau tidak ada sama sekali ambilan talium 201, berarti pada daerah tersebut terjadi iskemia atau tidak ada aliran darah sama sekali. Daerah ini disebut sebagai area dingin (cold spot) (Weiner,2000).

- Biasanya penyebab hasil positif palsu pada perfusion imaging adalah konduksi yang abnormal, khususnya pada left bundle branch block. Pada keadaan ini exercise echocardiography akan lebih sensitif untuk mendeteksi kelainan arteri koroner anterior kiri (Yanowitz,2000)

\section{Nilai Diagnostik Uji Latih Jantung pada Penyakit Jantung Koroner}

Uji latih jantung bermanfaat dalam menegakkan diagnosis penyakit jantung koroner dengan melihat gambaran perubahan EKG pada saat uji latih dibandingkan dengan pada saat istirahat. Terdapat dua manfaat yang dapat 
diperoleh dari uji latih jantung yaitu dapat menentukan kemampuan sirkulasi koroner dalam menaikkan suplai oksigen ke miokardium serta dapat menentukan kapasitas latihan untuk menilai kemampuan jantung menaikkan cardiac output (Irawan, 1997) .

Rangsangan simpatis yang timbul pada saat uji latih jantung akan meningkatkan frekuensi serta kontraksi jantung. Keadaan ini akan dapat meningkatkan derajat metabolisme jantung serta menimbulkan dilatasi arteri koronaria. Kenaikan frekuensi jantung tersebut dapat menunjukkan kebutuhan oksigen miokardium sehingga frekuensi jantung bisa digunakan sebagai parameter kebutuhan oksigen miokardium. Oleh karena itu, diagnosis penyakit jantung koroner dapat secara tidak langsung diketahui dengan melihat kenaikan frekuensi jantung pada orang yang melakukan uji latih jantung (Sugiri, 1996) .

Pada saat istirahat jantung mengambil sekitar $70 \%$ oksigen dari tiap unit darah yang mengalir ke miokardium, sehingga praktis metabolisme miokardium keseluruhannya adalah aerobik. Pada oran okcigen miokardium akan berakibat naiknya aliran darah koroner untuk memenuhi kebutuhan tersebut. Pada penderita penyakit jantung koroner kenaikan tersebut tidak bisa dicukupi karena adanya gangguan pada pembuluh koroner. Gangguan perfusi jaringan tersebut pada akhirnya dapat menimbulkan iskemia miokardium dengan keluhan nyeri dada, disfungsi ventrikel, serta gangguan irama jantung (Verani, 2000)

Iskemia miokardium yang terjadi selama latihan timbul akibat berbagai faktor, misalnya fase diastolik yang memendek, kenaikan respons simpatis, kebutuhan oksigen miokardium yang meningkat karena meningkatnya kontraksi otot jantung serta penyediaan oksigen miokardium yang tidak memadai hingga terjadi gangguan keseimbangan antara suplai dan kebutuhan (Yanowitz, 2000)

\section{KESIMPULAN}

Uji latih jantung merupakan uji yang sangat bermanfaat untuk menilai berbagai jenis kelainan jantung, akan tetapi dalam pelaksanaanya harus memperhatikan aspek keamanannya. Dengan adanya uji latih jantung ini dapat dibuktikan bahwa peran olahraga (exercise) tidak hanya pada aspek prevensi, promosi, terapi dan rehabilitasi namun juga dapat berfungsi sebagai sarana diagnostik. Uji latih jantung dapat dikombinasikan dengan prosedur diagnostik lain berupa elektrokardiografi, ekokardiografi maupun perfusion imaging. 


\section{Daftar Pustaka}

Anonim. (1997) Acute Coronary Syndrome, Including Acute Miocardial Infarction in Advanced Cardiac Live Support. American Heart Assosiation 19 - 30

Guyton AC, Hall JE. (1997) Aliran Darah dan Curah Jantung dalam Otot; Sirkulasi Koroner serta Penyakit Jantung Iskemia dalam: Fisiologi Kedokteran, edisi 9, EGC Jakarta:, 317 - 330

Heger J W, Roth RF. (1995) Uji Stres Latihan dalam Kardiologi, edisi 3.: Penerbit Buku EGC, Jakarta; $97-110$.

Irawan B. (1997) Exercise Electrocardiogram Test. In: Fundamental and Emergency in Cardiology and Cardio - Thoracic Surgery.: Faculty of Medicine Gajah Mada University. Yogyakarta;; $77-90$.

Kusmana D, Hanafi M. (1996) Patofisiologi Penyakit Jantung Koroner dalam Kardiologi Jakarta: Balai Penerbit FKUI,; $159-65$

Rahman AM. (1996) Penyakit Jantung Koroner Kronik. Manifestasi Klinis dan Prinsip Penatalaksanaan dalam Ilmu Penyakit Dalam, edisi 3, Jilid I. Jakarta: Balai Penerbit FKUI, 1091 - 97

Sugiri. (1996) Elektrokardiografi pada Uji Latih Jantung dalam ILmu Penyakit Dalam, edisi 3, Jilid I. Jakarta: Balai Penerbit FKUI,; 934 - 38

Trisnohadi H B. (1996) Angina Pektoris dalam Ilmu Penyakit Dalam, jilid I, edisi ketiga, eds. Balai Penerbit FKUI,; 1082 - 90

Verani MS. (2000) "Exercise Perfusion Testing in The Diagnosis of Coronary Heart Disease". http//www.uptodate.com,; 8: 3

$\longrightarrow$ (2000) "Stress Echocardiography in The Diagnosis of Coronary Heart Disease". http//www.uptodate.com,; 7: 13

- Weiner DA. (2000) "Determinant of Accuracy of Exercise ECG Testing in The Diagnosis of Coronary Heart Disease". http//www.uptodate.com; 7: 26

Yanowitz FG. (2000) 'Exercise ECG Testing Methodologies". http//www.uptodate.com, 4: 17

(1999) "Indications and Contraindications to Exercise ECG Testing". http// www.uptodate.com,; 6: 16 